S. M. Heiko, PhD., Associate Professor National University of Life Environmental Sciences of Ukraine, Heroiv Oborony Str. 15, Kyiv, 03041, Ukraine svt.geyko@gmail.com,

O. D. Lauta, PhD., Associate Professor National University of Life Environmental Sciences of Ukraine, Heroiv Oborony Str. 15, Kyiv, 03041, Ukraine elena.lauta@gmail.com

\title{
PHILOSOPHICAL CONNOTATIONS OF THE LEADERSHIP PHENOMENON
}

The article focuses on the phenomenon of leadership in philosophical discourse. Philosophical retrospection of the concept of "leadership" as a philosophical phenomenon and its systematic analysis is carried out. Philosophical connotations of the phenomenon of leadership in the dynamics of social and political processes of modern times are being defined.

In modern society, the well-formed image of leaders of organizations, movements and etcetera an important role. Leadership is a universal phenomenon of social life. It is present in any sphere of human activity that requires stratification: the separation of leaders and subordinates, leaders and followers.

In modern science, where there is a commonality of initial positions, leadership is characterized by ambiguity: as a social relationship of domination and subordination in a group or organization (sociology); as a characteristic of the figure of a leader and its impact on others (psychology); as effective and successful innovations in business, dominance in enterprise performance (economy); as developing vision, decision-making, empowerment and direction of people towards specific goals (management); as a process of human interaction in which authoritative people wield real power, exerting legitimate influence on a society that voluntarily gives them part of its political power and rights (political science).

The essence of leadership reveals its numerous concepts and theories that have evolved in the history of philosophy and social philosophy. Classical theorists tried to understand and develop the ideal concepts of leadership. Modern researchers are not analyzing the ideal of leadership, but what it is.

The philosophical understanding of leadership can be seen, first, as a form of power held by one individual or group of individuals; secondly, as a social position of decision-making; thirdly, as an influence on others.

Key words: leadership, leader, perspectives of research of leadership problem, social philosophy research.

Formulation of the problem. The relevance of social and philosophical analysis of the phenomenon of leadership derives from the complex dynamics of the current socio-political processes. The socio-economic and political processes that are taking place today continue to create opportunities for its diverse manifestations. There is a need to study the role and significance of leaders who are able to make decisions for others and influence people's actions and behaviour, to find rational solutions, to map out the future development of society. All this is of particular importance at the present stage of social development, when it is necessary to ensure the rationality, purpose, and efficiency of the whole process of governance.

The problem of the personality and its role in history has always been one of the most controversial in science. The history of philosophy has brought to us certain stages of development of the idea of leader. It originated in a cult of heroes in myths, resentments of different gods, which were identified with their earthly representatives - monarchs, rulers and so on. Interpreting the phenomenon of leadership. Later, the analysis of this phenomenon in one form or another is common to many philosophers who have speculated about the ideal state and its rulers. Although it is philosophy that has made a notable contribution to the study of leadership, contemporary philosophical studies have paid little attention to this problem.

At the beginning of Art. XXI, the problem of leadership became interdisciplinary. Psychology examines the personality of the leader, in particular the style of leadership of the group, the qualities that the leader should possess, the peculiarities of the perception of the female leader in the group, the methods of leadership of the group. Sociology considers leadership within the social system. Of particular importance today is the problem of leadership in political science, in particular the development of a legitimate procedure for the movement of the individual towards leadership in the structure of power, the possibility of managing this process, Adopting best practices for leaders to engage with their followers and opponents, different social groups and society as a whole.

The analysis of leadership as a philosophical concept gives the possibility to organically combine the historicalphilosophical material with the new theoretical development of modern Ukrainian and Western European science, to introduce into the wide scientific circulation still undeveloped by Ukrainian philosophers of sources. This topic appears on the fringes of the history of philosophy, social philosophy, social philosophy, sociology, psychology and political science, giving the opportunity in a new perspective to consider the social physiofolophy problem through the prism of the current issues and tasks of sociocultural existence.

Although the first attempts to understand the phenomenon of leadership were made by philosophers, conceptual approaches to the concept did not acquire a comprehensive philosophical foundation or theoretical generalization. The individual provisions on leadership had different origins and meanings, depending on the socialphilophotos context.

Analysis of research and publications. The problem of leadership has always attracted the attention of thinkers. In particular, the works of Plato, Aristotle, N. Machiavelli, T. Hobbs, J. Locke, J. Rousseau, G. Gegela, T. Carlyle, F. Nietzsche, Freida, E. Fromma, T. Adorno et al. addressing leadership issues, and which are considered fundamental in the philosophical development of the problem. The scientific concepts of these thinkers are the basis of modern theories of leadership.

G. Tard, 3. Freud, A. Petrovsky et al. (psychological aspect) contributed to the development of various theories of leadership that address the psychological, sociological, political and economic aspects of leadership M. Weber, G. Mosca, V. Pareto et al. (sociological aspect), U. Exton, G. Simon and others. (economic dimension) As well as eminent thinkers who explored the political dimension of the leadership problem, E. Bogardus (Theory of Traits), R. Stojdill (Situational Theory), E. Hollander (Exchange Theory), J. Burns (Transformative Theory), G. Gardner 
(Cognitive Theory), R. Lord, M. Hogg (Constructivist Theory). These studies generally complement.

The social and philosphical aspect of the problem is being studied by Russian scientists such as G. Ashin, Y. Gasilyna, B. Kretov, O. Kudryashov and O. Simagin. Among Ukrainian scientists, the problem of leadership is investigated by B. Kuhta, M. Mikhalchenko, A. Pakharyov, F. Rudić, J. Sulima and others.

An analysis of the degree of scientific development of the topic leads to the conclusion that, despite the existence of a substantial body of literature which, to a greater or lesser extent, covers various aspects of the problem chosen for the study, However, the state of its scientific understanding cannot be determined sufficiently. Not only has the notion of "leadership" not been a separate subject of study in domestic theoretical thought, but also because a number of focal points of a meaningful phenomenon have been overlooked by researchers.

Therefore, the purpose of this article is to recreate the philosophical retrospective of the emergence of the concept of "leadership" as a social-philophilia phenomenon and its systematic analysis, and to define its philosophical content in the dynamics of the social-political processes of the present time.

Exposition of the main material of the study. The first attempts at thinking about leadership have reached ancient times. Ancient thinkers have observed that where all societies are, there are bound to be leaders - the most experienced, the most powerful and the bravest people who win the support and recognition of their citizens. In heroes, monarchs and the warlords, they saw the true creators of history.

In the work of the "State" [6] Plato based the principles of an ideal State-society, based on the division of the population into three layers: helm, strategists and producers. Plato portrayed the leader-leader as a man of excellence, with a natural inclination to know, a love for truth, a strong rejection of lies. It is characterized by humility, nobility, justice, perfection. An ancient philosopher believed that authority was not power, but authority was the main instrument for managing society. And, to be credible, leaders must show restraint in meeting their needs, live a harsh lifestyle. They have liberated the right to own property because they undermine the moral foundations of the human being. The State should regularly conduct specialized training and carefully select the managers of the required intellectual background. The helmsman must know the welfare of the State. Knowledge also makes it possible to distinguish a true ruler from a false one. To Tom, Plato believes that the leaders are the helmsmen, whose power is combined with "understanding and reasoning", and the tools of control are gaining credibility.

Aristotle also drew a parallel between man and society. But, unlike Plato, he did not view society as a derivative of man as a state being, but rather as a derivative of society. According to him, a person outside the society-state is an abstraction, outside the society it is impossible, as it is impossible a living hand separated from the body. The ideal State for it is "a society that is level, united by one goal - to achieve the best possible life" [1].

Thus, Plato and Aristotle pondered the questions of how and why a man comes to power, and what purpose a leader sets for himself, using power. For philosophers, there was no doubt that a leader should want justice, honestly serve the state. Aristotle noted that participation in politics for a leader is the ultimate expression of human dignity. That is, ancient thinkers did not define "technological" (how to come to power?) but "normative aspects in the exercise of leadership roles (what should be known to those who seek power?).

Medieval European philosophers-theologians (Augustine Blizhenii, T. Akvynski, etc.) justified the rule of the ruler by the will of God. However, Renaissance thinkers are developing an ancient view of leadership.

Yes, at the head of his state, T. More puts the "wise" monarch, and in the "City of the Sun" T. Campanelli, as in the "State" of Plato, is led by a spiritual aristocracy. However, in Campanelli it is not a closed caste "with a special way of life and special education". At the head of state in Campanelli is not just a philosopher like Plato, but a high priest in one person.

N. Machiavelli made a significant contribution to understanding leadership. In contrast to the classical (normative, moral) approach to leadership, he focused on the issue of the pragmatic content of power by the leader, especially in times of change and instability. $\mathrm{N}$. Machiavelli was one of the first to give a detailed description of the leader-sovereign "This is a sovereign who unites, represents the whole society and uses any means, including cunning and force, to maintain his domination and maintain public order. A politician must combine the features of a lion and a fox : foxes - to avoid laid traps; lions - to crush the enemy in open combat" [4, pp. 47-122]. Therefore, Machiavelli was convinced: if it is about the maintenance of power, cunning and cruelty is the permitted tool, their use is not connected with justice and responsibility.

Prominent New Age thinkers (T. Hobbs, J. Locke, S. Montesk, F. Voltaire, G. Gegel, K. Marx) gave great importance to the issue of leadership, But there is a convergence that leadership is a kind of social-political need for people to organize themselves. hus, the development of capitalism brought the heroic leaders closer to the masses. At the same time, it provoked attempts to restore the long-standing ideas of leadership, to update them, to bring them closer to the realities of Europi XIX-XX.

The English philosopher T. Carlyle was one of those who reverted to the theme of the prominent role of personalities, "heroes" in history. Beyond Carlyle, there is a kind of historical circle, or cycle. When the heroic in society weakens, the secret destructive forces of the masses (revolutions and revolutions) can break out, and they act until society again finds "true heroes", chiefs, helmsmen (such as Cromwell or Napoleon) [3]. This approach drew attention to the role of individuals, and set out to uncover the reasons for the instability of their role in history. However, one cannot fail to notice the flaws of this approach : only "heroes" were considered, society was rigidly divided into helms and masses, the causes of revolutions were reduced to social feelings, ets.

Carlyle's views defined the views of the German philosopher F. Nietzsche, who had been one of the first to declare the will to power the driving force of history. He saw in the will to power a creative instinct that gives itself first of all to leaders who not only constantly seek to identify power and its application, but also overcome the inertia of the crowd because they are endowed with superhuman qualities. For Nietzsche, the pursuit of leadership is the natural aspiration of a man on the path of which morality emerges ("weapons of the weak"), the true leader has the right to persecute her so that she "is not a burden on his feet" [5]. Thus, for the first time, F. Nietzsche sees the nature of leadership as an 
irrational, instinctive force that binds the leader and his followers, as well as endowing the leader with outstanding qualities that turn him into a superhuman.

Nietzsche's approach was close to interpretations of leadership in European social psychology of the middle to the end of the 19th century. Such scientists as G. Lebon, G. Tard, etc. The nature of leadership has been interpreted in a similar way by everyone, each in their own way, and generally in a similar way: seen in the leader's will that nucleus around which crystallizing and unifying thoughts are around. This approach to leadership is also implicit in its perception of it as a dual - rational-willed but also irrational-instinctive - phenomenon.

A significant contribution to the analysis of the phenomenon of leadership was made by the Austrian scientist Z. Freud [7], who tried to explain people's desire for leadership. According to Freud, containment of libido is sublimated to the desire for leadership, and the neuroplant that accompanies this process forces the individual to seek ways of self-assertion, one of which is leadership. Freud noted that people in groups instinctively put themselves in positions of submission, and those who assert power quickly become leaders and maintain their positions if they represent the ideal characteristics of the group and have power. Under such conditions, the personality of the leader and his idea is influential. The influence of a leader, in turn, is based on the emotional, not the rational, so much more important than the content of ideas is their presentation.

The leader will retain his influence as long as he helps the team achieve its goals. According to Freud, it is also important to create the illusion that the leader treats all members of the group alike: people want to submit to the leader if they feel that they have the same position in their relationship with the leader. Hence, Freud's theory notes the emotional disposition towards the leader by followers, as well as the importance of emotional influence by the leader. Neo-freudists E. Fromm and T. Adorno followed in this direction, and their refinements greatly broadened the understanding of the intrinsic motivation of the leadership drive.

A significant contribution to the modernization of the leadership problem was also made by European sociologists from the late 19th to the 20th century.

German philosopher and sociologist M. Weber singled out three types of leadership: traditional leadership, which relies on the mechanism of tradition, ritual, strength of habit; charismatic, which allows exceptional qualities of the leader himself, which he actually owns or who are attributed to him by his environment; rational-legal (democratic) leadership, which is based on the existing legal framework in society. If the first type of leadership is based on habit, the second on intelligence, then the charismatic type of leadership relies on faith and emotion, which can create a situation of blind worship of the masses, produce conditions, when individual qualities of a leader play a secondary role in shaping his charisma. Weber pays particular attention to the analysis of charismatic leadership. He defined this type of leader as a generator of renewal of society in times of crisis, because the charismatic helmsman and his authority are not connected to the past, capable of mobilizing masses to solve social renewal tasks. In relatively calm periods of development, rational and legal leadership that preserves historical traditions and implements necessary reforms is acceptable to the society [2, pp. 354-360, 420-432].

Representatives of this direction of leadership research are also Italian sociologists V. Pareto (introduced the concept of "elite", formed the theory of the circulation of elites) and G. Mosca (introduced the concept of "political class"). They make generalizations about leadership as a social phenomenon: the consideration of the individual in its social capacity and its relationship to society, and the place and role of leadership in the functioning of society.

XX Art. has become a sometimes pluralistic concept of leadership. There are a number of theories in which the phenomenon of leadership is seen as an important mechanism for regulating the relations of actors in the political system - individuals, groups, institutions. First of all, it is the theory of personality traits, the essence of which is to explain leadership by the outstanding qualities of the face. Among the traits of the leader, her theorists (E. Bogardus et al.) highlight the keen mind, firm will, boiling energy, extraordinary organizational skills, the ability to please people and especially the willingness to assume responsibility, competence, as well as photogenicity, external attraction, oratory skills, ets. It is clear that, in a competitive environment, the psychological and social qualities that leaders really need are defined in order to take high positions. However, their diversity varies considerably, depending on the historical epochs and characteristics of the individual States of the world.

The idea of leadership, but depending on time, place, and circumstance, develops and validates the theory of situations. From the point of view of the situation, leadership qualities are relative: the behavior of the leader, his positions are suitable in one situation but not in others. The limitations of the theory lie in the fact that the leader's activities are insufficiently disclosed, his ability to turn the tide, the earlier to protect and exploit progressive tendencies.

These theories have their roots in the history of philosophy. The origin of the theory of traits can be seen in the writings of Plato, for whom the leader of the ideal state is the representative of one of three states - a rulerphilosopher, wise and just, free from material concerns, with a natural train to knowledge and with a love for truth. Such a leader creates a story. Situational theory is traced in the work of Aristotle and N. Machiavelli. Aristotle recognized the need to elect leaders because of their origin, material status, and good character (traits), but noted that the right form of state could only emerge when there was a "right" leader. Machiavelli's writings contain a series of rules-recommendations for the ruler, which include not only qualities worth developing, but also advice on how to behave according to the circumstances and how to build relationships with followers and enemies.

Theories of leadership that have developed since the middle of the 20th century. have some similarities with previous ones, and try to solve problems that have arisen before. These include the theory of believable roles of followers (W. Blanc, R. Stoodyll), exchange theory (E. Hollander) and transformational leadership theory (J. Burns). Whereas previously the main element of leadership was the personality of the leader, his traits, behavior, influence of the situation on activity, the first theory focuses its attention on followers, their relations with the leader. The exchange theory has much in common with the concept of a "social contract": in exchange for peace and security, the people give their power to the ruler. Hence, leadership is justified when it ensures such an exchange, otherwise people have the right to change the leader - an idea that was put forward by T. Hobbs and J. Locke. The theory of transformational leadership relates to the ideas of J.-J. Russo: The leader must be able to 
change human nature, turn the individual into a citizen who would participate in decision-making.

Most modern leadership theories (relational, cognitive, and constructivist) represent the synthesis of their predecessors: they consider both the leader and his behavior, the situation in which his activities take place, and his relationships with his followers. Within the framework of relational theory, the aspect of decisionmaking is analyzed, the effect of different decisions on the desire of followers to support the leader. In this context, procedural fairness is more important for distribution. It is the will of people to submit (and then to support) to decisions that are based on the recognition of fairness in the decision-making process itself, rather than on their possible utility.

Scientists attribute this fact to the fact that people feel more able to assess the fairness of the decision-making procedure than to predict the consequences of decisionmaking. Generally, scholars point out, honest, unbiased leaders who are concerned about people's needs (and thus share the values of these people) are perceived as such that can ensure a fair decision-making process. Under such circumstances, the individual legitimizes the activities of the leader and voluntarily obeys him. This idea resonates with Freud's ideas of emotional affection for the leader.

Within cognitive theory, leadership is seen as a form of social cognition. In particular, the American researcher G. Gardner notes the important role of the leader's words, which then feed into whole stories. The main element of leadership is seen by the scientist in the creation and implementation of identity stories: leaders tell stories about "themselves and their groups, where they come from, where they go, what they fear, what they fight against and what they dream of" [8, pp. 14]. The main characters in these stories are the leader and followers. The stories are dynamic: over time they unfold and through the activities of the leader become real events.

Constructivist theory, also known as the group of implicit theories, focused on the study of people's perceptions of leaders (the "leadership scheme"). The American researcher $R$. Lord highlighted a number of traits of character with which a leader is often associated: competence, honesty, understanding, determination and education. The Lord's research has documented that people do form some generalized views of leadership, which are later judged by the leadership potential of strangers (prototypes of leadership). It is worth noting that the majority of onchains in this direction share the idea of $Z$. Freud.
Conclusion. Philosophical theories of the phenomenon of leadership, firstly as a form of power held by one person or group of persons; secondly as a social position. The development of modern leadership theories is not linear: some theories have been transformed into others, some continue to influence new theories. For a significant part of the theories that develop in the XXI century. Classical theorists, who analyzed the phenomenon of leadership behind these basic directions, were significantly influenced by the need to institutionalize leadership, to recognize one type of leader, (a just sage who gives a country laws saves it in difficult times) and the reorganization of political institutions.

\section{СПИСОК ВИКОРИСТАНИХ ДЖЕРЕЛ}

1. Арістотель. Політика ; пер. з давньогрец. та передм. О. Кислюка / Арістотель - К. : Основи, 2000. - 239 с.

2. Вебер М. Избранные произведения ; пер. с нем. / М. Вебер. М. : Прогресс, 1990. - 808 с

3. Карлейль Т. Герой. Почитание героев и героическое в истории. I Т. Карлейль // Теперь и прежде. - М. : Республика, 1994. - С. 6-199.

4. Макиавелли Н. Сочинения: Государь ; пер. Муравьевой Г. Н. Макиавелли. - М. : ЗАО Изд-во "ЭКСМО-Пресс"; Х. : Изд-во "Фолио", 2001. Серия "Антология мысли". - 656 с.

5. Фрідріх Ніцше. По той бік добра і зла (Прелюдія до фрілософії майбутнього). Генеалогія моралі ; пер. $з$ нім. А. Онишко / Ф. Ніцше. - Л. : Літопис, 2002.- 320 с.

6. Платон. Держава ; пер. з давньогрец. Д. Коваль. - К. : Основи, 2000. -355 c.

7. Фрейд 3. Томас Вудро Вильсон. 28-й президент США: Психологическое исследование / З. Фрейд, У. Буллит. - М. : Прогресс, 1992. $288 \mathrm{c}$.

8. Gardner H. Leading minds: An anatomy of leadership / H. Gardner. N. Y. : Basic Books, 1995. -416 p.

\section{REFERENCES}

1. Aristotel (2000). Polityka [Polisy]. Kyiv, Osnovy (In Ukrainian).

2. Veber, M. (1990). Yzbrannye proyzvedenyia [Selected works]. Moskow, Prohress (In Russian).

3. Karleil, T. (1994). Heroi. Pochytanye heroev y heroycheskoe $v$ ystoryy [On Heroes. Hero-Worship and the heroic in history]. Moskow, Respublyka (In Russian).

4. Makyavelly, N. (2001). Sochynenyia: Hosudar [The Prince]. Moskow, ZAO Yzd-vo EKSMO-Press; Kharkov: Yzd-vo "Folyo" (In Russian).

5. Nitsshe, F. (2002). Po toi bik dobra i zla (Preliudiia do filosofii maibutnoho). Henealohiia morali [Beyond Good and Evil. Prelude to a philosophy of the future]. Lviv, Litopys (In Ukrainian).

6. Platon. (2000). Derzhava. [Republic]. Kyiv, Osnovy (In Ukrainian).

7. Freud, S., Bullitt, W. C (1992). Thomas Woodrow Wilson; TwentyEighth (28th) President of the United States: A Psychological Study. Moskow, Prohress (In Russian).

8. Gardner, H. (1995). Leading minds: An anatomy of leadership. N. Y., Basic Books.

\section{С. М. Гейко, канд. фрілос. наук, доц}

Національний університет біоресурсів і природокористування України, вул. Героїв Оборони, 15, м. Київ, 03041, Україна,

О. Д. Лаута, канд. філос. наук, доц.

Національний університет біоресурсів і природокористування України, вул. Героїв Оборони, 15, м. Київ, 03041, Україна

Received Editorial Board 18.10.20

\section{ФІЛОСОФСЬКІ КОНОТАЦІї ФЕНОМЕНУ ЛІДЕРСТВА}

Присвячено аналізу феномену лідерства у філософському дискурсі. Здійснено філософську ретроспективу становлення поняття "лідерство" як філософського феномену та його системний аналіз. Визначено філософські конотації феномену лідерства в динаміці соціально-політичних процесів сьогодення.

У сучасному суспільстві важливу роль відіграє правильно сформований імідж лідерів організацій, рухів тощо. Лідерство - універсальний за своєю природою феномен суспільного життя. Воно присутнє в будь-якій сфері людської діяльності, для існування якої потрібна стратифікація: виділення керівників і підлеглих, лідерів і послідовників.

У сучасній науці, за наявності спільності вихідних позицій, лідерство характеризується неоднозначно: як соціальні відносини домінування та підкорення у групі або організації (соціологія); як особливість постаті лідера та його вплив на інших (психологія); як ефективні й успішні інновації в бізнесі, домінування за показниками діяльності підприємства (економіка); як розробка бачення, прийняття рішень, наділення повноваженнями і спрямування діяльності людей на досягнення конкретних цілей (менеджмент); як процес взаємодії між людьми, під час якого наділені реальною владою авторитетні люди здійснюють легітимний вплив на суспільство, яке добровільно віддає їм частину своїх політико-владних повноважень і прав (політологія). 
Сутність лідерства розкривають його численні концепції та теорії, що склалися в історії філософії та соціальній філософії. Теоретики-класики намагалися осягнути та розробити ідеальні концепції лідерства. Сучасні дослідники аналізують не ідеали лідерства, а те, яким воно є насправді.

У межах філософського пізнання феномен лідерства може розглядатися, по-перше, як різновид влади, носієм якої є одна людина або група осіб; по-друге, як соціальна позиція, пов'язана із прийняттям рішень; по-третє, як вплив на інших людей.

Ключові слова: лідерство, лідер, основні теорії лідерства, типи лідерства, соціально-філософське дослідження.

С. Н. Гейко, канд. филос. наук, доц.

Национальный университет биоресурсов и природопользования Украины,

ул. Героев Обороны, 15, г. Киев, 03041, Украина,

Е. Д. Лаута, канд. филос. наук, доц.

Национальный университет биоресурсов и природопользования Украины,

ул. Героев Обороны, 15, г. Киев, 03041, Украина

\section{ФИЛОСОФСКИЕ КОННОТАЦИИ ФЕНОМЕНА ЛИДЕРСТВА}

Статья посвящена анализу феномена лидерства в философском дискурсе. Осуществляется философская ретроспектива становления понятия "лидерство" как философского феномена и его системный анализ. Определяются философские коннотации феномена лидерства в динамике социально-политических процессов современности.

В современном обществе важную роль играет правильно сформированный имидж лидеров организаций, движений и т. д. Лидерство - универсальный по своей природе феномен общественной жизни. Он присутствует в любой сфере человеческой деятельности, для существования которой нужна стратификация: выделение руководителей и подчиненных, лидеров и последователей.

В современной науке, при наличии общности исходных позиций, лидерство характеризуется неоднозначно: как социальные отношения доминирования и подчинения в группе или организации; как особенность фигуры лидера и его влияние на других (психология); как эффрективные и успешные инновации в бизнесе, доминирование по показателям деятельности предприятия (экономика); как разработка видения, принятие решений, наделение полномочиями и направление деятельности людей на достижение конкретных целей (менеджмент); как процесс взаимодействия между людьми, в ходе которого наделенные реальной властью авторитетные люди совершают легитимное влияние на общество, которое добровольно отдает им часть своих политико-властных полномочий и прав (политология).

Сущность лидерства раскрывают его многочисленные концепции и теории, сложившиеся в истории философии и социальной философии. Теоретики-классики пытались понять и разработать идеальные концепции лидерства. Современные исследователи анализируют не идеал лидерства, а то, каким оно есть на самом деле.

В рамках философского познания феномен лидерства может рассматриваться, во-первых, как разновидность власти, носителем которой выступает один человек или группа лиц; во-вторых, как социальная позиция, связанная с принятием решений; в-третьих, как влияние на других людей.

Ключевые слова: лидерство, лидер, основные теории лидерства, типы лидерства, социально-философское исследование

І. Г. Адамська, канд. іст. наук, асист. Київський національний університет імені Тараса Шевченка, вул. Володимирська, 60, м. Київ, 01033, Україна iryna.adamska@gmail.com

\section{ОБРАЗ КУЛЬТУРИ УКРАЇНИ СЕРЕДНЬОВІЧНОӤ ДОБИ НА СТОРІНКАХ "ЧТЕНИЙ В ИСТОРИЧЕСКОМ ОБЩЕСТВЕ НЕСТОРА ЛЕТОПИСЦА"}

Історичне товариство Нестора Літописця у другій половині XIX - першій половині XX ст. займалось вивченням історії та культури України. Із 1888 р. почав регулярно виходити часопис товариства - "Чтения в Историческом Обществе Нестора Летописца". Мета цієї статmі - виявлення проблем з історії культури X-XVI ст ${ }^{1}$., які цікавили членів Історичного товариства Нестора Літописця та виносилися ними на сторінки часопису. Аналіз тематики праць учених, систематизація їхніх оцінок та інтерпретацій проблем культури дають змогу визначити роль, що надавалась середньовічній культурі українських земель у розвитку самобутності цієї території. Водночас акцентується саме на визначенні комплексу тем з історії культури, які стали предметом історичного, а частково і суспільно-політичного дискурсу другої половини XIX - початку XX cm. завдяки їхньому розгляду на сторінках часопису. 3'ясовано, що з другої половини XIX cm. учені все частіше звертались до давніших, аніж період козаччини, тем, щоб розкрити культурну самобутність "південноруських земель", виявити місцеві традиції та визначити іноземні впливи. Для цього дослідники звертались до вивчення пам'яток писемності та творів літератури, проводили дослідження 3 історії релігій, виявляли та аналізували мистецькі пам'ятки періоду Середньовіччя та раннього Нового часу, вивчали міжнародні культурні зө'язки Русі.

Ключові слова: культура України, Середньовіччя, Історичне товариство Нестора Літописця, історіографія XIX ст.

Постановка проблеми. У XIX ст. популярності набуває дослідження археографічних, археологічних, архітектурних, етнографрічних пам'яток. Цим почав займатися створений у 1835 р. Тимчасовий комітет для дослідження старожитностей у Києві, з 1843 р. - Тимчасова комісія для розбору давніх актів при Київському, Волинському і Подільському генерал-губернаторі. Збиранням творів мистецтва та заснуванням музею займалися члени створеного у 1897 р. Києвського товариства старожитностей і мистецтв. А в 1910 р. виникло Київське товариство охорони пам'яток старовини і мистецтва, яке мало не тільки вивчати пам'ятки культури, але й організовувати їх збереження, реставрацію та охорону [7; 62; 63; 66]. 3 другої половини XIX ст. до подібної роботи активно долучалися історичні та церковно-археологічні товариства. Історичне товариство Нестора Літописця, створене у 1872 р., не було виключенням. Його члени також займалися пошуками та вивченням різних пам'яток культури. Результати досліджень вони публікували у спеціалізованих періодичних виданнях та у вигляді окремих праць, а з 1879 р. почали також видавати власний часопис - "Чтения в Историческом Обществе Нестора Летописца" (далі - "Чтения..."). ${ }^{1}$

Аналіз досліджень і публікацій. Загальну інформацію про створення та діяльність Історичного товарис-

1 До уваги бралися праці, присвячені X-XVI ст. Верхня межа виходить за межі Середньовіччя, але водночас охоплює лише невелику частину ранньомодерного періоду, у зв'язку 3 чим у назві другий етап не відображено. 